\title{
Effect of Carbon Content on Bainite Transformation Kinetics and Microstructure of 4140/4150 Steels
}

\author{
Jian Zhu, MS \\ Xichen Sun, PhD \\ Gary Barber, PhD \\ Xue Han, MS \\ Hao Qin, BS
}

Fiat-Chrysler LLC/USA, Oakland University, USA

Doi: 10.19044/esj.2019.v15n9p518 URL:http://dx.doi.org/10.19044/esj.2019.v15n9p518

\begin{abstract}
4140 steel and 4150 steel are different only in their carbon content. A comparison between the kinetics and microstructure of the bainite transformation of both steels has been carried out under a wide range of isothermal temperatures, in which four bainite phase matrices were generated. The four phases are upper bainite, mixed upper and lower bainite, lower bainite and mixed martensite and lower bainite (lower bainite transformed under Ms temperature). The bainite transformation kinetics-morphology characteristics of the four phases were studied and compared. Kinetics behavior patterns are shown with the developed TTT diagrams and kinetics plots - (bainite volume fraction vs isothermal holding time). The upper bainite and lower bainite transition temperatures are different and the bainite reaction time span is shorter when carbon content is higher. The $\mathrm{n}$ values in the Johnson-Mehl- Kolmogorov-Avrami (JMKA) equation have a wider deviation when carbon content is higher, indicating more bainite reaction variation. The activation energy required for the bainite phase transformations were compared and it was found that higher activation energy is needed when carbon content is higher. The subtle microstructure morphology differences are illustrated. This work will aid future development of 4140/4150 steels with bainitic microstructures having improved mechanical properties.
\end{abstract}

Keywords: Carbon content effect, Iso-thermal, Upper and lower bainite, Transformation Kinetics, Activation energy

\section{Introduction}

Carbon plays an important role in bainite (Davenport and Bain, 1930) transformation in the austempering process. Carbon atoms need to diffuse or 
partition out quickly within the super saturated bainitic ferrite plate once it forms (Bhadeshia, 1992) and they also need to diffuse or partition in the parent austenite. Since the diffusion or partition rate of carbon in ferrite is much faster than the rate in parent austenite, the carbon atoms movement and distribution (Timokhina et al, 2016) at the interface between ferrite and austenite in localized areas will greatly affect the transformation kinetics. The transformation kinetics can be diffusion controlled or interface controlled (Sietsma and van der Zwaag, 2004; J Seol, Raabe, Choi, Im, Park, 2012). More carbon will precipitate either outside or within the bainitic ferrite, depending on the isothermal holding temperature (Bhadeshia, 1992; Azuma et al, 2005; Lawrynowicz, 2017; J Wang et al, 2000; Keehan et al; Suikkanen, Karjalainen $\&$ DeArdo, 2009) to form upper bainite, or lower bainite or a mixture of both. Other than carbide precipitation, the carbon atoms may be trapped at dislocations in the vicinity of the ferrite austenite interface, which prevents the complete decarburization of the super saturated ferrite (Caballero, Miller, Babu \&Garcia-Mateo, 2007; Caballero, Miller, Clarke \& Garcia-Mateo, 2010). Local carbon enrichment slows down the bainite transformation kinetics since carbon has a stabilization role in austenite (Catteau et al, 2016).

The content level of carbon plays a critical role in bainite transformation. Local carbon content poor areas will promote bainitic ferrite nucleation. The carbon trapped in local areas between the ferrite phases will accelerate the bainite transformation (Rees \& Bhadeshia, 1992). A critical carbon content level will determine when the bainite transformation stops, and whether the bainite reaction is complete or incomplete (Bhadeshia \& Waugh, 1982; Hillert, Höglund \& Ågren, 2004). Depending on the steel carbon content, the bainite start temperatures vary in a range. Usually an increase in carbon content gives rise to a decrease in bainite start temperature Bs, the rate of decrease depends on the cooling rate ( Kawata, Fujiwara \& Takahashi, 2017 \& 2018; Kang, Yoon \& Lee, 2014). A reduction in the carbon content increases the phase transformation temperature and prompts various bainitic ferrite variants, but the sensitivity of the phase transformation to cooling rate is reduced (Catteau et al, 2016). When the transformation temperature is lowered to around the Ms, the martensite start temperature, the carbon content's kinetics deceleration effect will have to compete with pre-existing martensite's acceleration efforts (Navarro-Lopez, Sietsma \& Santofimia, 2015; NavarroLópe \& Sietsma, 2016; Durand-Charre, 2004). The carbon content and carbon related activities will affect the bainite transformation kinetics and the bainite microstructures and morphology, which in turn affect the mechanical properties of the austempered heat-treated steel generated by a specific isothermal process.

4140/4150 steels are popular in many applications such as industrial structures, hard tooling and tool bodies, and advanced automotive parts such 
as transmission gears and engine sprockets. Austemperied heat-treated $4140 / 4150$ steels offer a variety of material properties in terms of strength, ductility, hardness, and toughness that makes them suited for many industry applications. The carbon content difference between 4140 and 4150 is only $0.1 \%$. This is the only difference in composition between the two steels. This research work addresses the kinetic and morphological characterization produced by the carbon content difference of the $4140 / 4150$ bainitic steel family. The isothermal holding temperatures studied covers a wide range, from well below Bs to well below Ms, the martensite start temperature. This research will aid the future development of $4140 / 4150$ steels with bainitic microstructures with the improved mechanical properties.

\section{Experimental Procedures}

\section{Material}

The chemical composition of the $4140 / 4150$ steels is listed in Table 1. The as-received 4140/4150 steels have a hardness ranging from $25.6 \mathrm{HRC}$ to 32 HRC. The steels as-received have microstructures consisting of proeutectoid phases embedded in a pearlite matrix.

Table 1. 4140/4150 Steel Chemical Composition (wt. \%)

\begin{tabular}{|c|l|l|l|l|l|l|l|l|c|}
\hline Element & $\mathrm{Cr}$ & $\mathrm{Mn}$ & $\mathrm{C}(4140)$ & $\mathrm{C}(4150)$ & $\mathrm{Si}$ & $\mathrm{Mo}$ & $\mathrm{S}$ & $\mathrm{P}$ & $\mathrm{Fe}$ \\
\hline Wt (\%) & $0.8-1.1$ & $0.75-1.0$ & $0.38-0.43$ & $0.48-0.53$ & $0.15-0.3$ & $0.15-0.25$ & 0.04 & 0.035 & Balance \\
\hline
\end{tabular}

Heat Treatment and Experiment Scheme

Samples of both 4140 and 4150 steels were austenitized at $854^{\circ} \mathrm{C}$ for 20 minutes. Seven isothermal temperatures were utilized as shown in Figure 1. The isothermal holding temperatures started at $454^{\circ} \mathrm{C}$ with $28^{\circ} \mathrm{C}$ decrements and finished at $288^{\circ} \mathrm{C}$. With this isothermal temperature range, the following phases or mixed phases were produced: a) Upper bainite, b) Mixed upper and lower bainite, c) Lower bainite and d) Mixed lower bainite and martensite. For each isothermal temperature, nine isothermal holding times were studied. After austenitizing 20 minutes in a salt bath furnace, the steel samples were dropped into an isothermal holding furnace within 1 second and then held in the holding furnace for $10,30,60,90,120,150,300,600$ or 900 seconds respectively. Once the isothermal holding time was complete, the sample was dipped into water at room temperature to freeze the bainite transformation status so the exact amount of bainite transformed could be determined through hardness measurement for kinetics calculations. The isothermal holding temperatures were selected from below Bs, to below Ms. The martensite start temperature was approximated using the TTT diagram in the ASM Heat Treater's Guide. Samples of both steels were measured with a hardness tester using HRC scale and also were polished and etched with $2 \%$ nital. Microstructure images obtained on the samples were taken using a light 
optical microscope with 500X magnification. Selected samples were also studied using SEM.

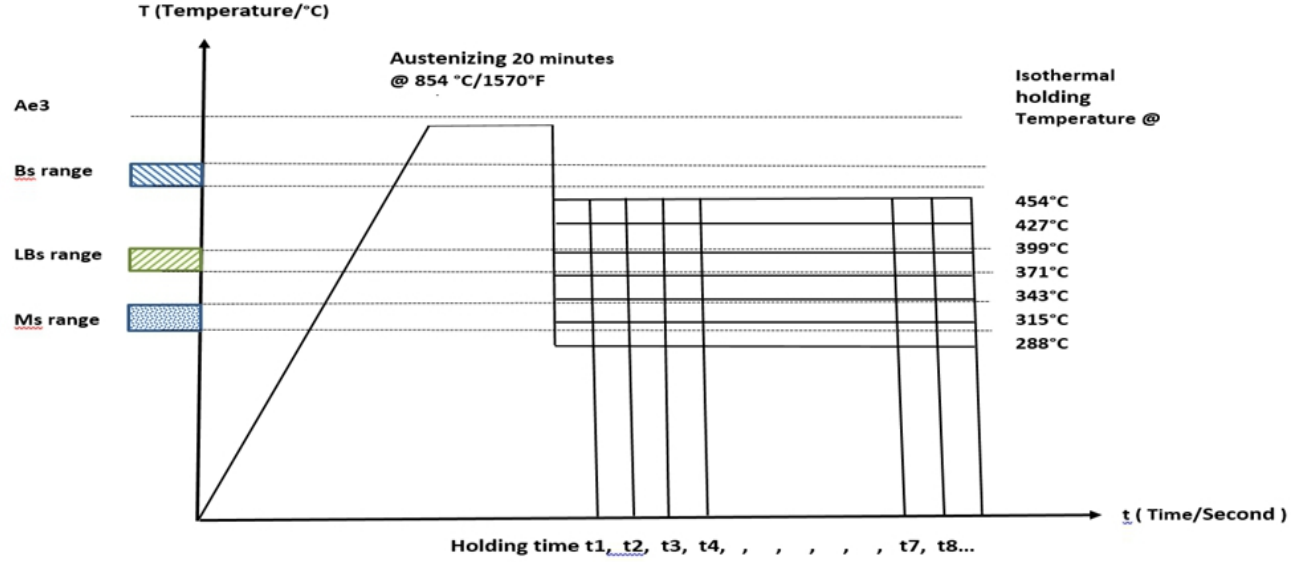

Figure 1. 4140/4150 steel austempering heat treatment

\section{Results and Analysis}

Hardness Achieved

Figures 2 and 3 show the hardness variations of samples collected before or at the beginning of bainite transformation. As the bainite transformation proceeds, the hardness values of the samples decreased. The hardness data indicates the bainite transformation status in the transformation process since the hardness measured is directly related to the volume or quantity of bainitic microstructure transformed. Comparing Figure 2 to Figure 3 , at 10 seconds after isothermal treatment, 4140 steel samples show lower hardness than 4150 steel samples at all isothermal temperatures. This indicates that the bainite transformation started for the 4140 steel much earlier than the 4150 steel due to the lower carbon content. When carbon content increases, carbon will have more impact on the bainite transformation and will postpone or retard the bainite transformation due to the thermodynamic driving force reduction. The hardness data measured will be used in the following sections to calculate the bainite volume fraction according to the hardness changes with the increase of the isothermal holding time at a certain isothermal temperature. 


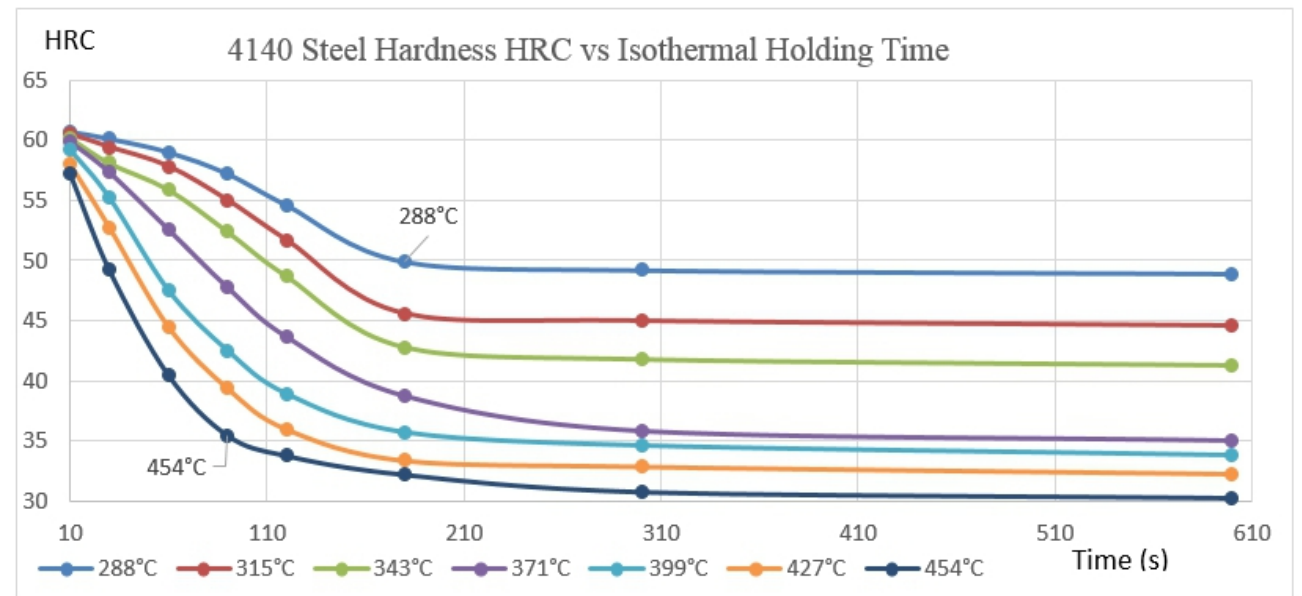

Figure 2. 4140 steel hardness

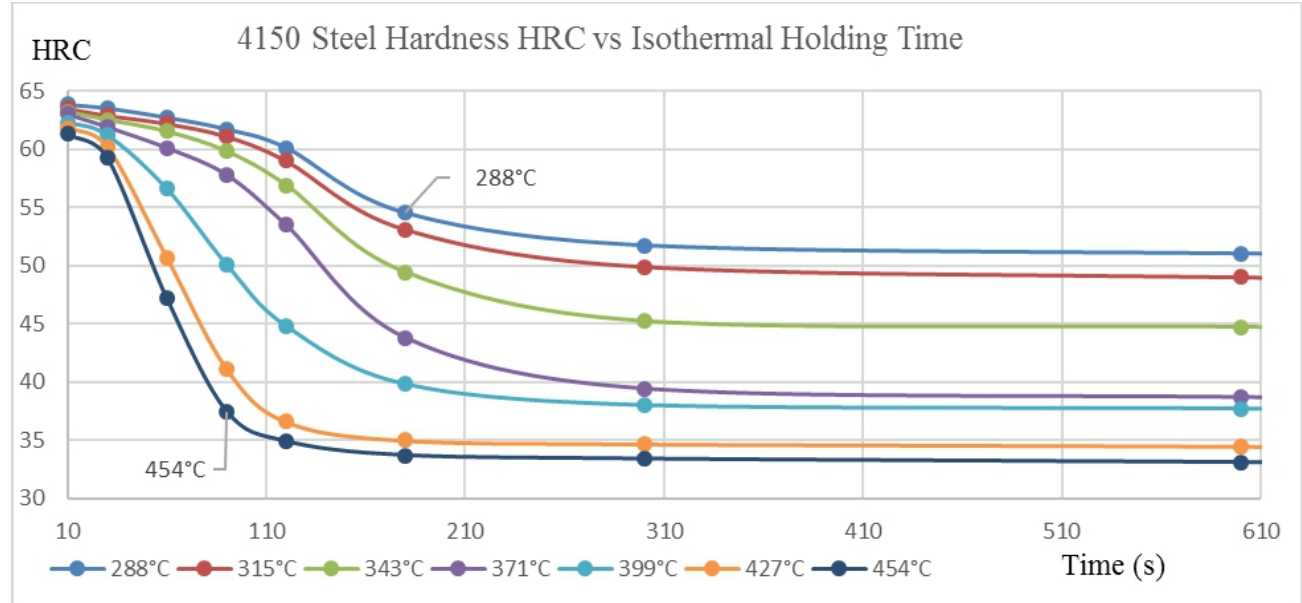

Figure 3. 4150 steel hardness

Transformation Kinetics and TTT Diagram

Steel sample hardness is a function of bainite transformation since hardness is determined by the bainitic microstructures achieved during the isothermal process. By understanding the hardness changes as a function of bainitic microstructure volume fraction changes along the isothermal holding time at a certain temperature and estimating the bainite transformation start and finish time with the help of LOM photos, the bainite transformation rate can be calculated. Using equation (1) and the hardness data, bainite transformation volume fraction $\mathrm{X}(\mathrm{t})$ can be calculated as:

$$
X(t)=\frac{H_{0}-H(t)}{H_{0}-H_{f}}
$$


$\mathrm{X}(\mathrm{t})$ : bainite transformation volume fraction at time $\mathrm{t}$; Ho: initial hardness when bainite transformation starts; Hf: final hardness when bainite transformation ends; $\mathrm{H}(\mathrm{t})$ : hardness at isothermal bainite reaction time $\mathrm{t}$.

In Figure 4, for the 4140 steel, the kinetic curves can be clearly classified into two groups. The first group is for the curves of $454^{\circ} \mathrm{C}, 427^{\circ} \mathrm{C}$ and $399^{\circ} \mathrm{C}$. The bainite volume fraction curves have a common pattern. They have the shape of an asymptote to a limit when the transformation is finished. With the microstructures observed, it can be seen that they belong to the upper bainite group. The second group is for the curves of $343^{\circ} \mathrm{C}, 316^{\circ} \mathrm{C}$ and $288^{\circ} \mathrm{C}$, they have a typical Sigmund shape. With microstructure analysis, they are identified as curves for lower bainite. The curve at $371^{\circ} \mathrm{C}$ is the transitional one, with microstructure analysis, it is identified as a mixture of upper and lower bainite. The transformation seems accelerated, possibly due to lower bainite nucleation on the upper bainite boundaries. With the data calculated using equation (1), the 4140/4150 steel bainite transformation fraction vs holding time charts are plotted in Figure 4 and Figure 5.

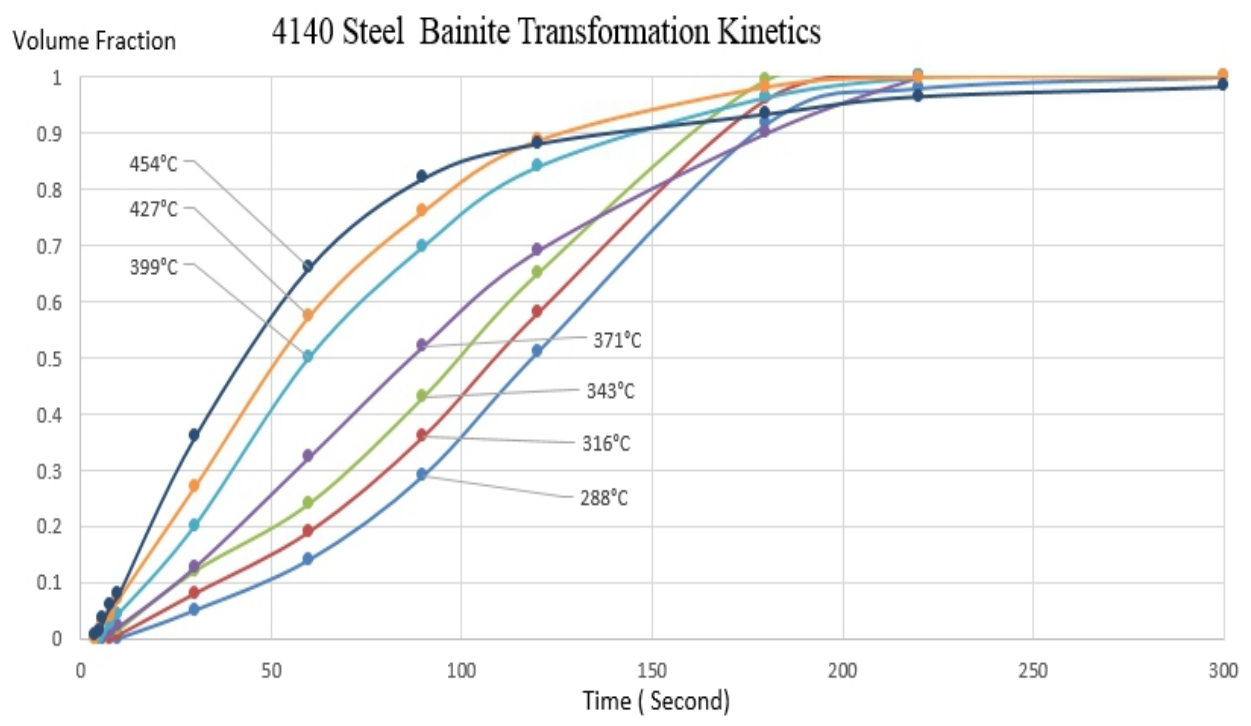

Figure 4. 4140 steel bainite reaction kinetics

In Figure 5, for the 4150 steel, the kinetic curves initiated much later and also finished later, the bainite transformation was retarded. It seems that the bainitic ferrite nucleation and incubation needs longer time compared to the 4140 steel due to the increased carbon content. The curves can also be grouped into two as was done for the 4140 steel. 
Volume Fraction

4150 Steel Bainite Transformation Kinetics

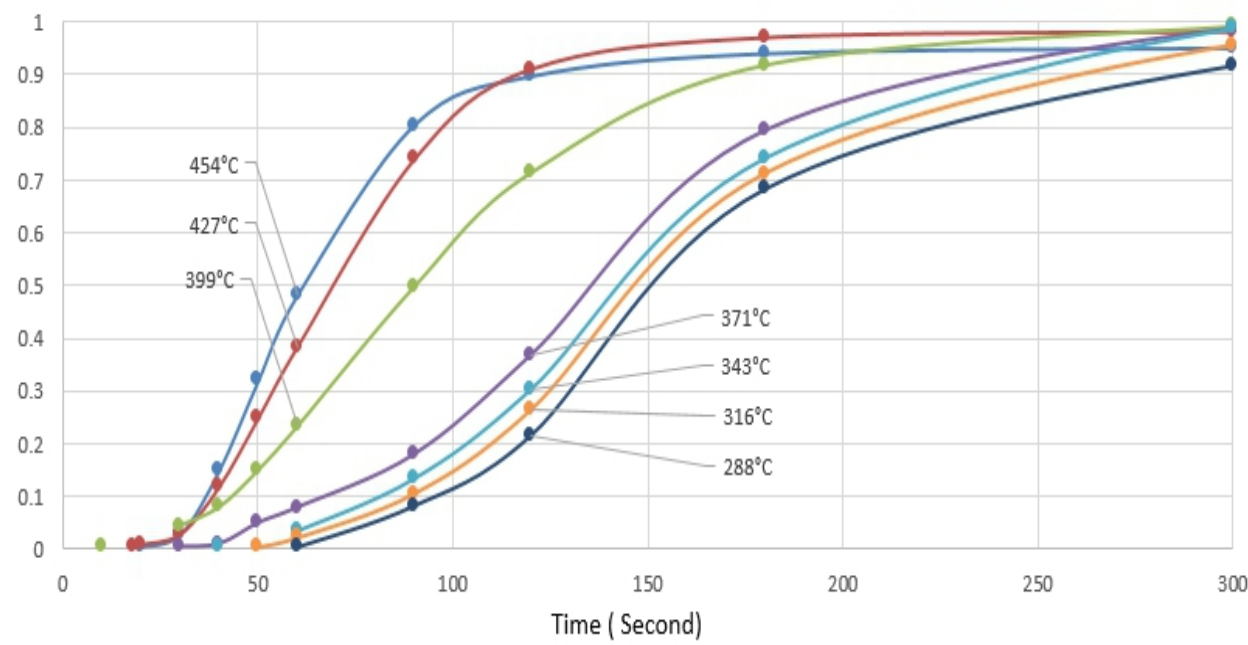

Figure 5. 4150 steel bainite reaction kinetics

One difference is that the transitional curve, which reflects the mixture of upper and lower bainite, is at $399^{\circ} \mathrm{C}$. Above it are the curves for the 4150 upper bainite, below it are the curves for the lower bainite. The transitional temperature identified here is a little higher than the one for the 4140 steel. This occurs because more carbon will prompt carbide precipitation, when precipitation occurs with the bainitic ferrite, lower bainite will be generated.

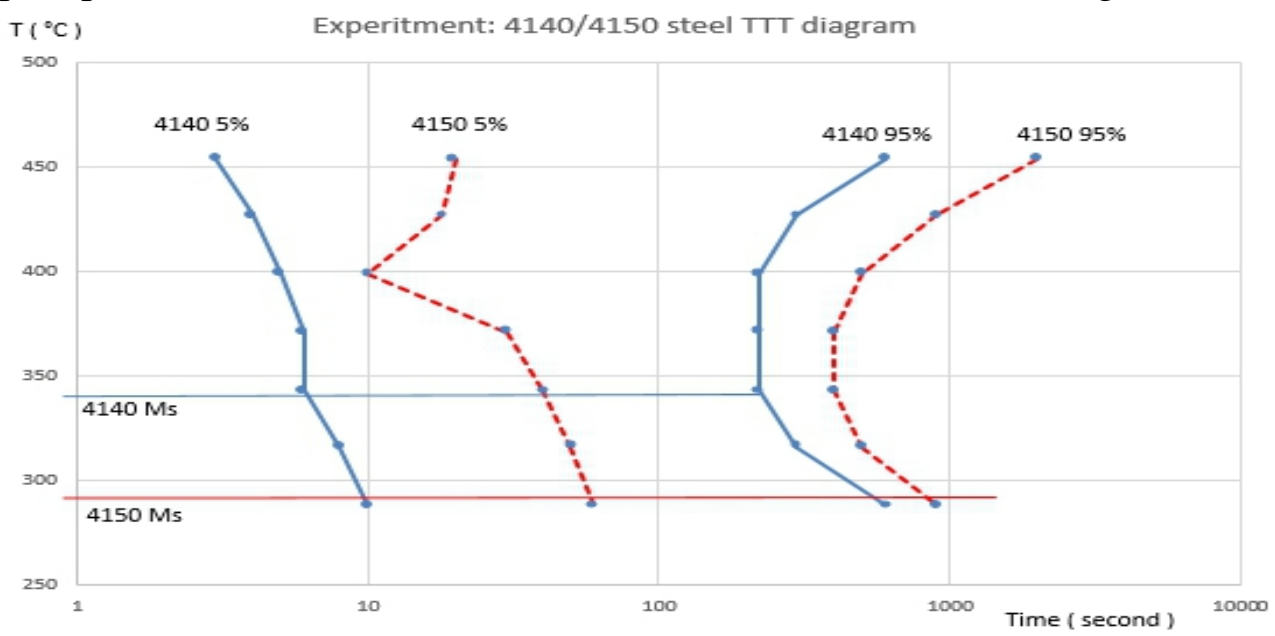

Figure 6. 4140/4150 steel TTT overlay diagram

In addition, the overall thermodynamic driving force for bainite transformation for both steels reduces and the transformation slows down when the undercooling or cooling rate becomes higher. Using the data and analysis above, a TTT diagram with limited temperature range is constructed 
for both steels. Figure 6 is the overlay of the TTT curves of the two steels. It is clear that the 4150 steel bainite transformation starts later and finishes later compared to the 4140 steel. The 4150 steel displays a $C$ type curve. The 4140 steel does not show a $\mathrm{C}$ curve perhaps due to the isothermal temperature range not being large enough. For 4140 steel, bainite transformation starts within 10 seconds under all isothermal temperatures. For the 4150 steel, however, transformation mostly starts after 30 seconds-and the overall diagram is shifted in the right and down direction including the Ms as compared to the 4140 steel.

\section{Bainite Transformation Kinetics}

Bainite transformation kinetics is very complicated and many factors can affect it. Numerous bainite transformation kinetic models have been developed in an effort to account for these factors (Durand-Charre, 2004). So far there is not a single model which has been accepted by all researchers except the Johnson-Mehl-Avrami-Kolmogorov equation or JMAK equation (Avrami, 1939). The bainite reaction kinetics can be expressed with the conventional functional model (Luo, Han \&Gu, 2016) -- Avrami equation, which describes the overall transformation kinetics. This model links the volume fraction $\mathrm{X}(\mathrm{t})$ and the bainite transformation reaction rate $\mathrm{K}$ together:

$$
X(t)=1-\exp \left(-K t^{n}\right)
$$

where $\mathrm{t}$ is the isothermal holding time, $\mathrm{K}$ is the bainite transformation reaction rate constant and $\mathrm{n}$ is the exponential constant, at a certain isothermal temperature. By applying a logarithmic operation, (2) becomes a linear equation between $\log (-\operatorname{Ln}(1-X))$ and $\log (\mathrm{t})$.

$$
\log (-\operatorname{Ln}(1-X))=n^{*} \log (t)+\log (K)
$$

Using this linear relationship, with the data from Figure 4 \& Figure 5, the $n$ and $\log (\mathrm{K})$ can be obtained through linear regression for all isothermal temperatures. Table 2 shows the summary of the $n$ and $K$ values obtained.

For the 4140 steel, the $n$ ranges from 1 to 2.23 with an average of 1.7 . According to Milosan 2008 and Christian 1965\&2002, the 4140 steel bainite reaction should be austenite and bainitic ferrite interface controlled. For the 4150 steel, the average $n$ is 2.3. In the upper bainite area it ranges from 1.18 to 1.93. It is also interface controlled. But for the lower bainite in the 4150 steel, the n ranges between 2.4 and 3.09, which represents plate shape with parabolic ferrite thickening with decreasing nucleation rate (Christian 2002 ). This is not consistent with the experimental behavior of the transformation. 
Table 2. Summary of $\mathrm{n}$ and K (Avrami constants) for the 4140/4150 bainite transformation kinetics

\begin{tabular}{|l|l|l|l|l|}
\hline $\begin{array}{l}\text { Isothermal } \\
\text { Temp }\left({ }^{\circ} \mathrm{C}\right)\end{array}$ & $\mathrm{n}(4140)$ & $\mathrm{n}(4150)$ & $\mathrm{K}(4140)$ & $\mathrm{K}(4150)$ \\
\hline 454 & 1.0655 & 1.1825 & 0.1083 & 0.001748 \\
\hline 427 & 1.3339 & 1.722 & 0.00361 & 0.000179 \\
\hline 399 & 1.5687 & 1.9376 & 0.00111 & $7.90 \mathrm{E}-05$ \\
\hline 371 & 1.737 & 2.7431 & 0.00035 & $7.53 \mathrm{E}-07$ \\
\hline 343 & 1.8018 & 3.0944 & 0.00023 & $9.62 \mathrm{E}-08$ \\
\hline 316 & 2.2056 & 3.0375 & $3.12 \mathrm{E}-05$ & $8.88 \mathrm{E}-08$ \\
\hline 288 & 2.2357 & 2.4163 & $1.32 \mathrm{E}-05$ & $1.25 \mathrm{E}-06$ \\
\hline Average & 1.71 & 2.3 & & \\
\hline
\end{tabular}

\section{Microstructure}

Figures 7 and 8 are photos of the upper bainite of the 4140 steel and the 4150 steel at $454 \mathrm{C}^{\circ}$ after 30 seconds isothermal holding time. They look very similar. The carbon content difference of the two steels does not produce any difference from the morphology standpoint. Figures 7 and 8 show the typical lath like acicular bainite sheaves. Upper bainite sheaves are short-fat lath-like structures. Due to being formed under relatively higher isothermal temperatures the microstructure is coarse.

There are fewer bainite regions in Figure 8 due to the 4150 steel bainite needing more incubation time. Figures 9 and 10 are photos of the 4140 and the 4150 steel upper bainite and lower bainite mixed microstructures. The microstructure of upper bainite consists of short-fat lath-like sheaves. The lower bainite consists of long-slim needle-like sheaves.

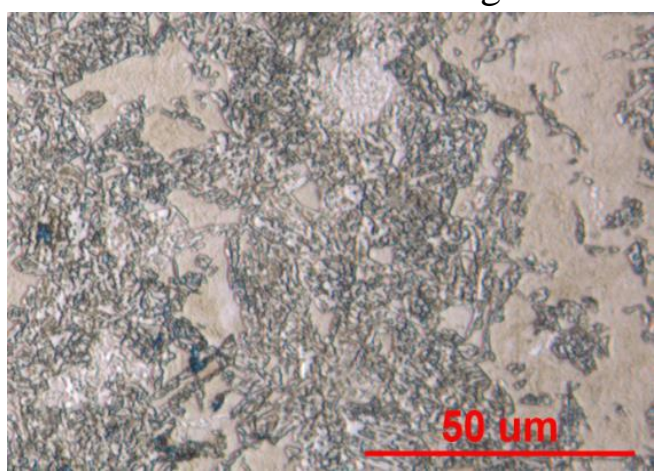

Figure 7. 4140 steel $454^{\circ} \mathrm{C} 30$ s $500 \mathrm{X}$, UB

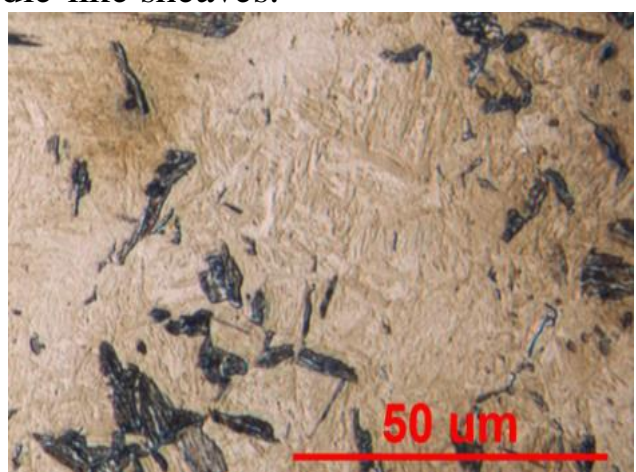

Figure 8. 4150 steel $454^{\circ} \mathrm{C} 30$ s $500 \mathrm{X}$, UB 


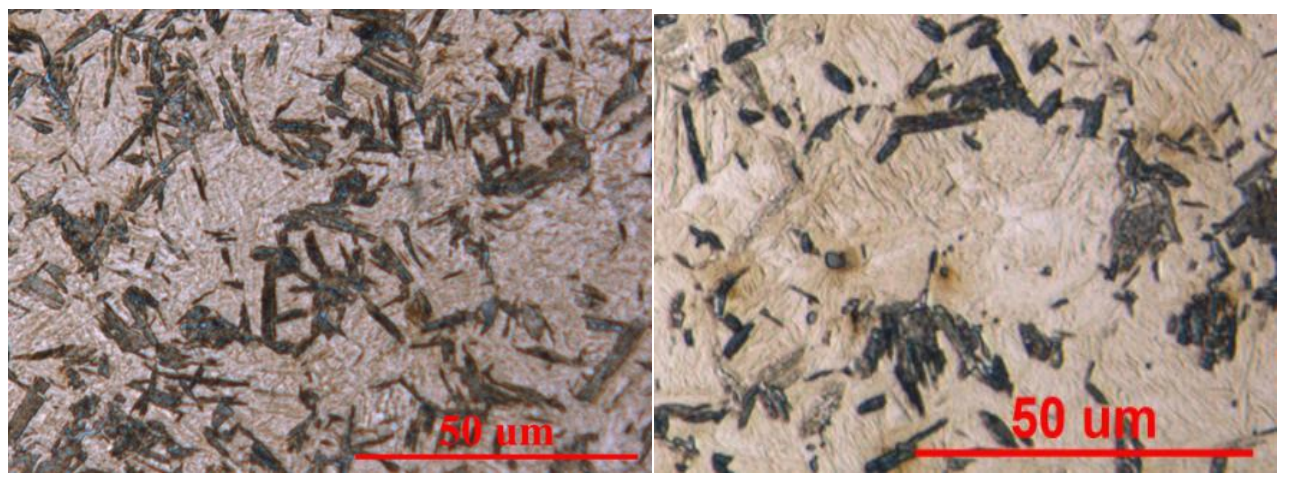

Figure 9. 4140 steel $371^{\circ} \mathrm{C} 60 \mathrm{~s} 500 \mathrm{X}, \mathrm{UB} / \mathrm{LB}$ Figure 10.4150 steel $399^{\circ} \mathrm{C} 30 \mathrm{~s} 500 \mathrm{X}, \mathrm{UB} / \mathrm{LB}$

Figures 11 and 12 show the photos of the 4140 and the 4150 steel with lower bainite produced at an austempering temperature of $343^{\circ} \mathrm{C}$. They show typical lower bainite from the morphorlogy stand point. 4150 steel shows fewer bainite regions. Due to the carbon content effect, for the 4140 steel, the Ms is around $343 \mathrm{C}^{\circ}$. Therefore below this isothermal temperature, martensite and lower bainite mixed microstructures will be obtained and typical acicular lower bainitic ferrite plates are formed. Figure 13 shows the photo of this condition. Due to preexisting martensite, the lower bainite transformation is slightly accelerated.
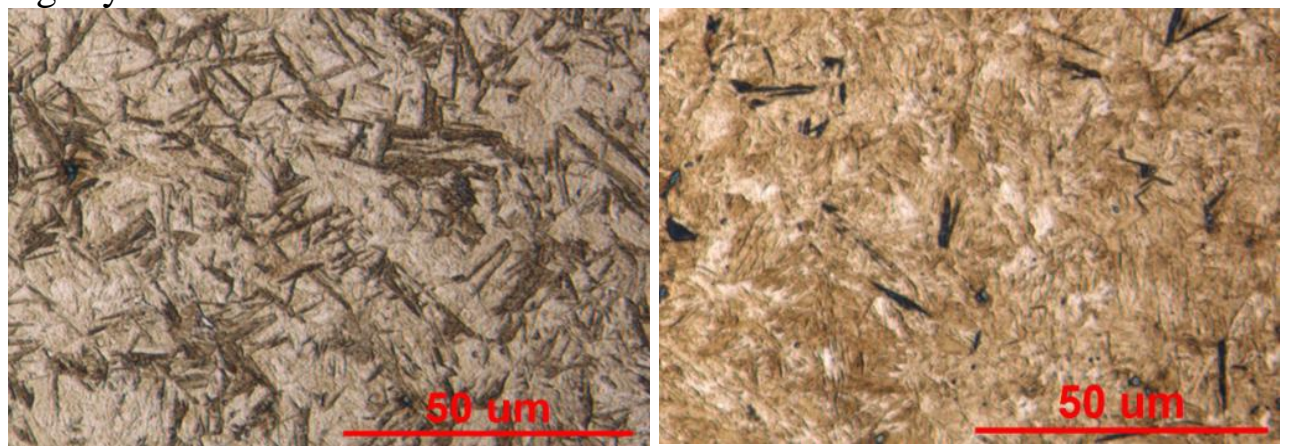

Figure 11. 4140 steel $343^{\circ} \mathrm{C} 60 \mathrm{~s} 500 \mathrm{X}, \mathrm{LB}$
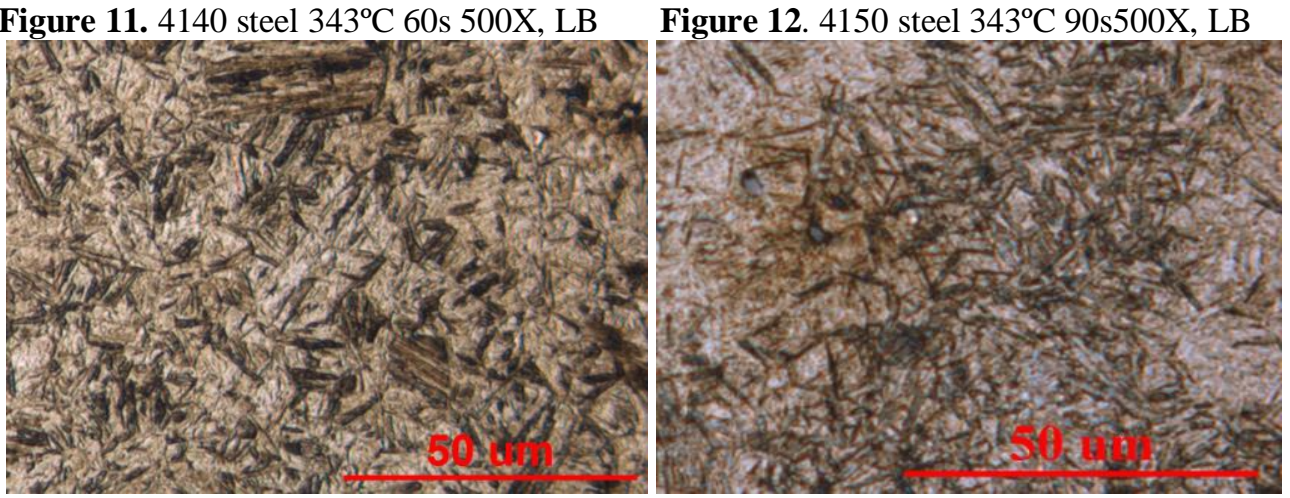

Figure 13. 4140 steel $316^{\circ} \mathrm{C} 60$ s $500 \mathrm{X}, \mathrm{M} / \mathrm{LB}$ Figure 14. 4150 steel $288^{\circ} \mathrm{C} 90 \mathrm{~s} 500 \mathrm{X}, \mathrm{M} / \mathrm{LB}$ 
For the 4150 steel, the $\mathrm{Ms}$ is around $288 \mathrm{C}^{\circ}$, which is much lower compared to the 4140 steel. The lower bainite sheave is typically a fine slimlong, needle-like microstructure. This is due to very fine carbide preciptation within and around the bainitic ferrite plates. Figure 14 shows this condition after isothermal holding for 90 seconds at $288 \mathrm{C}^{\circ}$. There is not much difference between the 4140 and the 4150 steel in terms of morphology in the isothermal temperature range in this study, carbon content difference does not make a difference in the middle carbon range of this steel family from the microstructure standpoint.

Scanning Electron Microscopy (SEM) was also performed on the samples of austempered at $316^{\circ} \mathrm{C}$ for 90 seconds on both steels for observation under larger magnification. As shown on Figures 15-16, the dark needle like areas are the bainitic ferrites and the white dots are carbides. The ferrites plates are thinner and finer in the 4140 steel compared to the ones in the 4150 steel, which are coarse and wider, due to the increase of carbon content decreasing the bainite and martensite start temperatures in the austempering process.
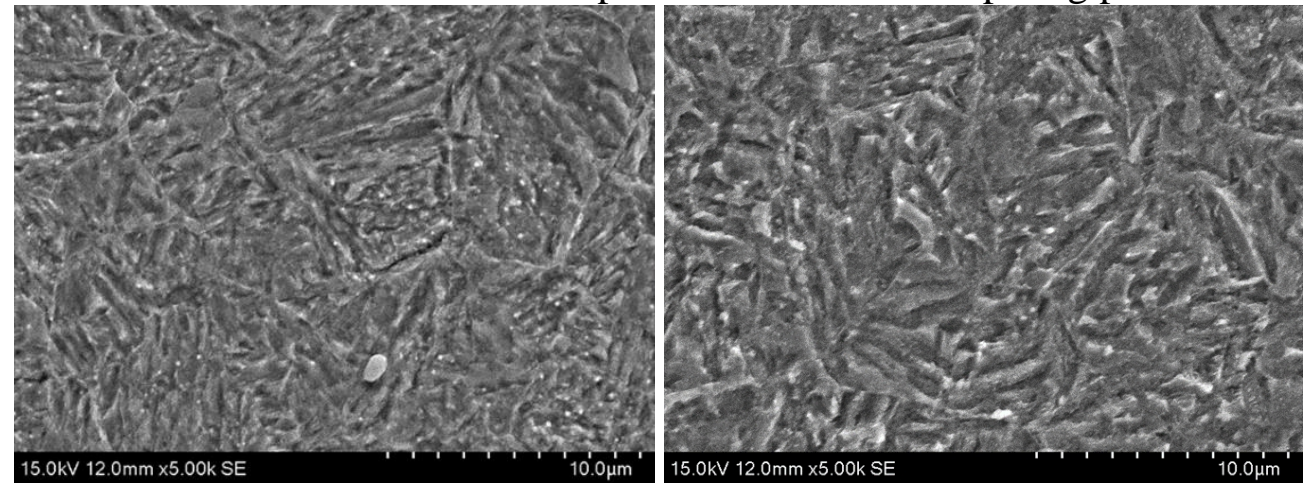

Figure 15. 4140 steel $316^{\circ} \mathrm{C}$ 90s, SEM X5000 Figure 16. 4150 steel $316^{\circ} \mathrm{C}$ 90s, SEM X5000

\section{Activation Energy}

Free energy change is the thermodynamic driving force for the bainite transformation. The transformation activation energy is directly linked and proportional to the driving force. The activation energy Q (Kang, Zhang, Liu $\&$ Zhu, $2009 \& 2009$ ) at reaction percentage $x$ is defined as:

$$
Q_{x}=R\left[\frac{\partial(\ln (K))}{\partial\left(\frac{1}{T}\right)}\right]_{x}
$$

Where $\mathrm{K}$ is the bainite reaction or phase transformation rate. The activation energy $\mathrm{Q}$ can be associated with transformation reaction rate $\mathrm{K}$ in the Arrhenius equation (Arrhenius, 1899).

$$
K=A \exp (-Q / R T)
$$


Q: Bainite transformation activation energy [J/mol]

A: Bainite transformation reaction frequency factor [ $1 / \mathrm{s}]$

R: General gas constant $8.31\left[\mathrm{~J} / \mathrm{mol}^{*} \mathrm{~K}\right]$

$\mathrm{T}$ : Iso-thermal temperature in which bainite is transformed $[\mathrm{K}]$

By taking the natural logarithm of both sides of equation (5), a linear equation as shown below can be derived, in which $\operatorname{Ln}(\mathrm{K})$ and 1/T have a linear relationship.

$$
\operatorname{Ln}(\mathrm{K})=\operatorname{Ln}(\mathrm{A})-(\mathrm{Q} / \mathrm{R}) *(1 / \mathrm{T})
$$

Once $\mathrm{T}$ and $\mathrm{Ln}(\mathrm{K})$ are known, $-(\mathrm{Q} / \mathrm{R})$ and $\operatorname{Ln}(\mathrm{A})$ can be obtained through linear regression. Then $\mathrm{Q}$, the activation energy is determined through calculation. Some researchers chose to use the reaction constant $\mathrm{K}$ in the Avrami equation as the reaction rate (Bosnjak \& Radulovic 2004; Wei \& Wang, 2015). In this case the $\mathrm{K}$ calculated with equation (6) can be used to calculate activation energy with equation (4).

The iso-thermal temperatures selected for this research cover a wide range of temperatures in which four groups of microstructures are transformed. The four groups are upper bainite, upper bainite and lower bainite mixture, lower bainite, and martensite and lower bainite mixture. With the experimental data, based on the K obtained via the Avrami equation (Hillert, Höglund \& Ågren, 2004; Durand-Charre 2004), the activation energy for the four groups of microstructures transformed in the experiments were calculated.

The results in Table 3 show the overall bainite transformation average activation energy of the 4140 steel QB is $136 \mathrm{KJ} / \mathrm{mol}$ while it is $183 \mathrm{KJ} / \mathrm{mol}$ for the 4150 steel. This value is close to the diffusion activation energy of carbon in austenite, which is $131 \mathrm{KJ} / \mathrm{mol}$ or $148 \mathrm{KJ} / \mathrm{mol}$ (Gegner 2012; Agren 1986). This is because super saturated carbon atoms from the bainitic ferrite plate need to diffuse into the parent austenite quickly once formed. Diffusion certainly is a viable process if the temperature is high enough. The 4150 steel has higher carbon content than the 4140 steel has, so the activation energy required should also be higher.

When the reaction temperature is in the upper bainite area, the activation energy for 4140 steel is $167 \mathrm{KJ} / \mathrm{mol}$ (Zhu, Sun, Barber, Han \& Qin 2018) and for the 4150 steel is $220 \mathrm{KJ} / \mathrm{mol}$. Higher activation energy is again required for the 4150 steel. When the reaction temperature is lower, for instance in the lower bainite transformation area, the activation energy for 4140 and 4150 steel QLB is $50 \mathrm{KJ} / \mathrm{mol}$ and $119 \mathrm{KJ} / \mathrm{mol}$ respectively. 
Table 3. 4140/4150 steel bainite transformation activation energy

\begin{tabular}{|l|l|c|l|}
\hline Microstructure & $\begin{array}{l}\text { Activation } \\
\text { Energy(KJ/mol) }\end{array}$ & $\begin{array}{l}4140 \\
\text { Steel }\end{array}$ & $\begin{array}{l}4150 \\
\text { Steel }\end{array}$ \\
\hline Upper Bainite (UB) & QUB & 167 & 220 \\
\hline Upper + Lower Bainite (UB+LB) & QUBLB & 98 & 115 \\
\hline Lower Bainite (LB) & QLB & 50 & 119 \\
\hline Lower Bainite + Martensite (LB+M) & QLBM & 86 & 261 \\
\hline Bainite Overall (B) & QB & 136 & 183 \\
\hline
\end{tabular}

It is less than $131 \mathrm{KJ} / \mathrm{mol}$ for both steels, this can be explained by displacive theory (Bhadeshia 2001; Lawrynowicz 2002; Santofimia et al. 2006), which indicates that bainite transforms without diffusion (Reynolds, Aaronson \& Spanos, 1991). The results also show that upper bainite activation energy is higher than lower bainite activation energy in both steels. For the 4140 steel QUB $(166 \mathrm{KJ} / \mathrm{mol})>$ QLB $(50 \mathrm{KJ} / \mathrm{mol})$; for the 4150 steel QUB $(220 \mathrm{KJ} / \mathrm{mol})>\mathrm{QLB}(119 \mathrm{KJ} / \mathrm{mol})$. This agrees with previous research (Durand-Charre 2004; Kang, Zhang, Liu \& Zhu, 2009\& 2009).

The mixed microstructures of upper bainite and lower bainite in both steels have activation energy lower than upper bainite and higher than lower bainite at each carbon content level, QUBLB $<$ QUB and QUBLB $>$ QLB, this is due to the fact that they are in the transitional stage. The mixed microstructures of martensite and lower bainite also show higher activation energy than the lower bainite at each carbon content level, QLBM>QUB for both steels. This is because the bainite transformation is accelerated due to the preexisting martensite (Toji, Matusda \& Raabe, 2016), which requires more energy. The acceleration seems limited in the 4150 steel because the increased carbon content has a retarding effect on bainite transformation.

\section{Undercooling and Activation Energy/Hardness}

Undercooling creates the thermal dynamic driving force of the phase transformation, see Figure 17. The phase activation energy is proportional to the amount of undercooling or cooling rate. Figure 17 shows the trend, that when the cooling rate increases, the activation energy needed for phase transformation is reduced since upper bainite needs more activation energy compared to the lower bainite. However, the trend is reversed when undercooling is so large that the mixed phases of martensite and bainite were generated.This is due to the preexisting martensite accelerating lower bainite transformation and more activation energy was needed. As the under cooling increases, the bainite phase matrix composition also changes. The phase or mixed phases would be transformed and in turn affect the hardness of the bainitic steel. 


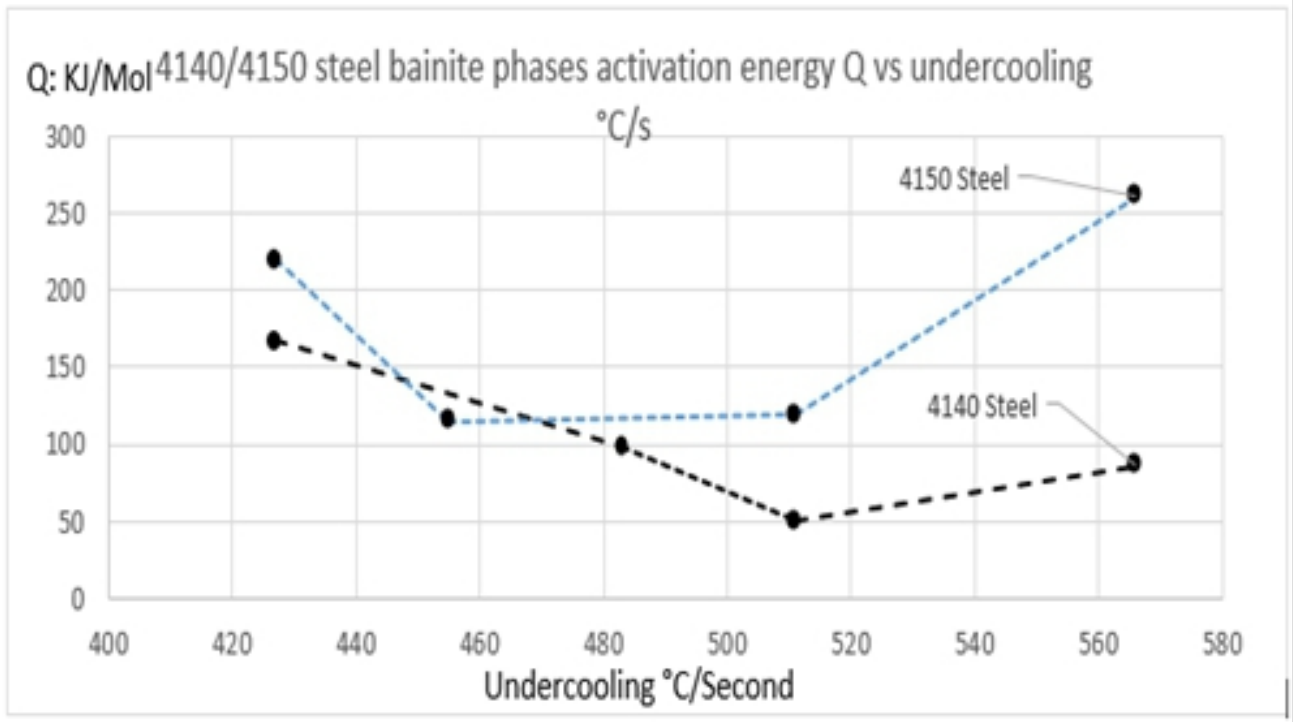

Figure 17. Undercooling and phase activation energy for 4140/4150 steel

For both steels, the trend is the same, the greater the undercooling or the cooling rate is, the harder the steel will be, as shown in Figure 18. 4150 steel has more carbon content and has higher HRC after being subjected to the austempering process. This is perhaps also due to more dislocations in the 4150 steel (Navarro-Lopez, Sietsma \& Santofimia, 2015 \& 2016; Toji, Matusda \& Raabe, 2016). The average hardness difference between 4150 and 4140 steel at the same undercooling condition ranges from 1.3 to $7.4 \mathrm{HRC}$.

4140 Steel Austemper Hardness vs Undercooling

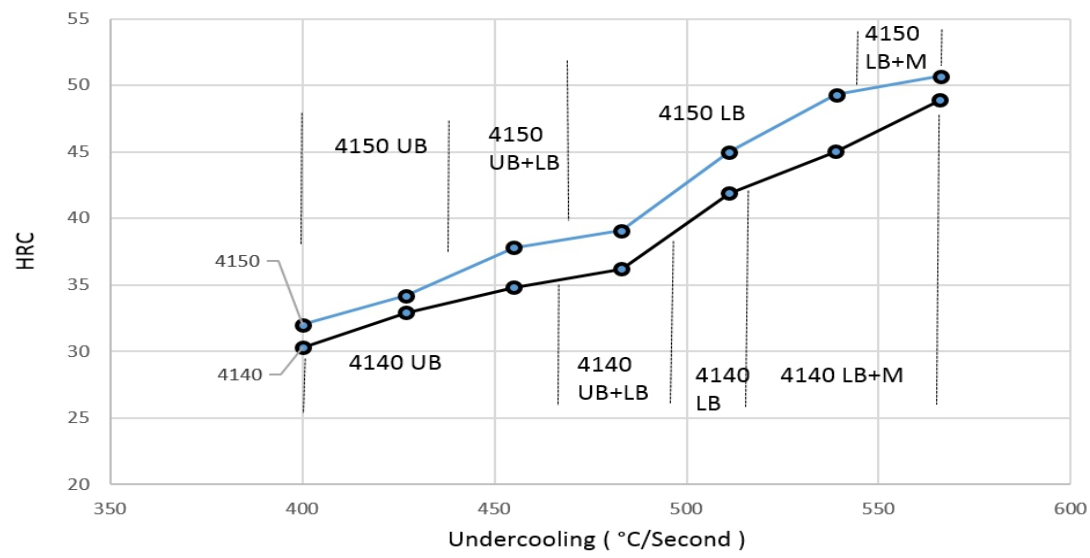

Figure 18. Undercooling and bainite steel hardness for the $4140 / 4150$ steel

\section{Summary and Conclusions}

An austempering isothermal process was carried out on both 4140 and 4150 steels over a wide temperature range. The heat-treated sample HRC data 
were collected and plotted against isothermal holding time. The plotted hardness data clearly shows differences between various isothermal temperatures. The hardness data indicates the bainite transformation status, since the hardness is directly related to the volume or quantity of bainitic microstructures transformed. With the experimental data, 4140/4150 bainite transformation kinetics, activation energies and microstructures were characterized.

Conclusions from this research are:

1) For both steels, the upper bainite kinetic curves behave differently than the lower bainite kinetic curves due to the manner in which carbon atoms diffuse/partition differently. Understanding this behavior will contribute to steel design and development.

2) The TTT diagram constructed from the experimental data shows that the 4140 steel bainite transformation starts earlier and finishes earlier compared to the 4150 steel at the same isothermal temperature. An increase in carbon content retards the bainite transformation and lowers the martensite start temperature pushing the TTT curves in the down and right direction in the diagram. This diagram can assist the $4140 / 4150$ steel process design and development for industry applications.

3) For the 4140 steel, the n values of JMKA range from 1 to 2.23 , which suggests the 4140 steel bainite transformation is austenite and bainite interface controlled. For the 4150 steel, the kinetics are more complicated, in the upper bainite transformation area, $\mathrm{n}$ is between 1.18 and 1.93 and is interface controlled. In the lower bainite area, $n$ is between 2.41 and 3.09, indicating a different nucleation and growth scenario where the transformation is parabolic ferrite thickening with decreasing nucleation rate, due to the higher carbon content in the steel.

4) The $4140 / 4150$ steel bainite transformation activation energies of all four microstructure groups were determined. The results agree well with many previous research results. For each group, the activation energy of the 4150 steel is higher than the 4140 steel. For overall bainite reaction activation energy, a similar trend occurs with $136 \mathrm{KJ} / \mathrm{mol}$ for the 4140 and $183 \mathrm{KJ} / \mathrm{mol}$ for the 4150 steel due to the carbon content difference. The higher the carbon content, the higher the bainite activation energy required.

5) For both 4140 and 4150 steel, lower bainite appears as a dark etching long-slim needle-like structure due to lower temperature transformation producing fine microstructure. Upper bainite appears as a dark etching short-fat lath-like structure due to the higher transformation temperature producing coarse microstructure. There is 
no significant difference in morphology between the 4140 and the 4150 steel even though the carbon content is different.

\section{References:}

1. Davenport E.S. and Bain E.S., Transformation of austenite at constant subcritical temperature. Trans Am Inst. Min. Metall Engng. 90: 117254, 1930

2. Bhadeshia H. K.D.H., Bainite in Steel, The Institute of Materials, London, 1992

3. Timokhina I.B., Liss K.D., Rabbe D., Rakha K., etal. Growth of bainite and carbon partitioning during the early stages of bainite transformation in a 2 mass\% silicon steel studied by in situ neutron diffraction, TEM and APT. Journal of Applied Crystallography, Feb 16,2016

4. Sietsma J.,Van der Zwagg S., A concise model for mixed-mode phase transformations in the solid state. Acta Materialia, Vol.52,14, p4143, 2004.

5. Seol J., Raabe D., Choi P., Im Y., Effect of alloying, partitioning, solute drag, and austempering on the mechanical properties of highcarbon bainitic-austenitic TRIP steels. Acta Materialia, Vol.60, 17, p6183, 2012.

6. Azuma M. and Fujita N. and Takahashi M. etc, Modeling Upper and lower bainite transformation in steel, ISIJ International, Vol.45 p221, 2005.

7. Lawrynowicz Z., Bainitic reaction and microstructure evolution in two normalized and tempered steels designed for service at elevated temperature. Advances in Materials Science, Vol.17, No.4, (54), 2017.

8. Wang J., Van der Wolk P.J., Van Der Zwaag S., On the influence of alloying elements on the bainite reaction in low alloy steels during continuous cooling. Journal of Materials Science, 35 p4393, 2000.

9. Keehan E., Karlsson L., Andren H.-O, Bhadeshia H.K.D.H., Influence of carbon, manganese and nickel on microstructure and properties of string steel weld metals, Part 3 - Increased strength resulting from carbon additions. Science and Technology of Welding and Joining, Vol.11, No.1, 2006

10. Suikkanen P., Karjalainen P., DeArdo A.J., Effect of carbon content on the phase transformation characteristics,microstructures and properties of 500 Mpa grade miroalloyed steels with non-polygonal ferrite microstructures. La Metallurgia Italiana, 2009.

11. Caballero F.G., Miller M.K., Babu S.S., Garcia-Mateo C Atomic scale observations of bainite transformation in a high carbon high silicon steel. Acta Materialia, Vol.5,1, p308 2007. 
12. Caballero F.G., Miller M.K., Clarke A. J., Garcia-Mateo C., Examination of carbon partitioning into austenite during tempering of bainite. Scripta Materiallia, 63(4), p442 2010.

13. Catteau S.D., Van landeghem H.P., Teixeria J., Dulcy J., etal; Carbon and nitrogen effects on microstructure and kinetics associated with bainite transformation in a low-alloyed steel. Journal of Alloys and Compounds, 658, p832, 2016.

14. Rees G.I., Bhadeshia H.K.D.H, Bainite transformation kinetics Part 2: Non-uniform distribution of carbon, Materials Science \& Technology, Vol.8, p985, 1992.

15. Bhadeshia H.K.D.H., Bainite: incomplete-reaction phenomenon, Acta Metall. 1982

16. Hillert M., Hoglund L.,Agren J., Role of carbon and alloying elements in the formation of bainite ferrite. Metallurgical and Materials Transactions, Vol.35A, p3693, 2004.

17. Kawata H., Fujiwara K.,Takahashi M., Effect of carbon content on bainite transformation start temperature in low carbon $\mathrm{Fe}-9 \mathrm{Ni}-\mathrm{C}$ alloys. ISIJ International, Vol.57, No.10, p1866, 2017.

18. Kawata H., Fujiwara K.,Takahashi M., Effect of carbon content on bainite transformation start temperature in middle-high carbon $\mathrm{Fe}$ 9Ni-C alloys. ISIJ International, Vol.58, No.1, p165, 2018

19. Kang S., Yoon S., Lee S., Prediction of bainite start temperature in alloy steels with different grain size. ISIJ International, Vol.54, No.4, p997, 2014.

20. Catteau S.D., Van landeghem H.P., Teixeria J., Dulcy J., etal; Carbon and nitrogen effects on microstructure and kinetics associated with bainite transformation in a low-alloyed steel. Journal of Alloys and Compounds, 658, p832, 2016.

21. Navarro-Lopez A., Sietsma J., Santofimia M.J., Effect of pre-existing martensite in a low-C high-Si steel. Int Conf on Solid Phase Transformation in Inorganic Materials, PTM 2015.

22. Hidalgo J., Sietsma J., Santofimia M.J., Effect of prior athermal martensite on the isothermal transformation kinetics below Ms in a low-C high-Si steel. Metallurgical and Materials Transactions, Vol.47A, pp1028-1039, 2016.

23. Durand-Charre, Microstructures of steel \& cast irons. Springer ISBN3540209638, 2004

24. Avrami, M., Kinetics of Phase Change. I. General Theory. Journal of Chem Phy 7 (12): p1103, 1939

25. Luo X., Han L., Gu J., Study on austenitization kinetics of SA508 Gr.3 steel based on isoconvensional method. Metals 6, 8; 2016 
26. Milosan I. Aspects about the kinetics and thermodynamic transformation of a special S.G. cast iron. $6^{\text {th }}$ International DAAAM 24-26 April 2008.

27. Christian, J.W., The theory of transformation in metals and alloys, Pergamon Press, New York, 1965.

28. Christian J.W., Theory of Transformations in Metals and Alloys, Elsevier Science Ltd. 2002.

29. Kang M., Zhang M., Liu F. and Zhu M., Overall transformation energy of isothermal transformation in metal alloy and its mechanism. Acta Metallurgica Sinica, Vol.45, No.1, p25, 2009.

30. Kang M., Zhang M., Liu F. and Zhu M., Kinetics and morphology of isothermal transformations at intermediate temperature in 15CrMnMoV steel. Materials Transactions, Vol.50, No.1 p123, 2009

31. Arrhenius S. A., Uber die Dissociationswarme und den Einfluss der temperature auf den Dissociationsgrad der Elektrolyte. Z Phys. Chem. 4: 96-116. DOI 10.1515/zpch-1889-0408

32. Bosnjak B., Radulovic B., Effect of Austenitising temperature on austempering kinetics of Ni-Mo alloyed ductile iron. Materiali in Techonologije, (MTAEC9) 38, 2004.

33. Wei D. Q., Lu J., Wang R., The effect on the properties of low-alloyed bainite ductile iron in oil quenching and isothermal tempering temperature. $5^{\text {th }}$ ICIMM 2015.

34. Gegner J., Vasilyev A., Alloy Dependence of the diffusion coefficient of carbon in austenite and analysis of carburization profiles in case hardening of steels. Proc.7th Int. Conf. 2012

35. Agren J., Revised expression for the diffusivity of carbon in binary FeC austenite. Scripta Metall. 20 (11) p1507 1986.

36. Zhu J., Sun X., Barber G., Han X., Hao Q.: Bainite Transformation Kinetics of a Cr-Mo Medium Carbon Alloyed Steel. Material Science \& Technology $2018 \quad$ Conference Proceedings, 2018. DOI/10.7449/2018/MST_2018_1081_1088

37. Lawrynowicz Z., Features of bainite transformation in steels. Advances in Materials Science, Vol.2, No.1 (2) 2002.

38. Santofimia M.J., caballero f. g., Capdevila C, etc, Evaluation of Displacive models for bainite transformation kinetics in steel, Materials Transactions, Vol.47, No.6, p1492, 2006.

39. Reynolds W.T., Aaronson H.I., Spanos G.: A summary of the present diffusionist views on bainite, Materials Transactions, JIM, Vol.32, No.8 p737, 1991

40. Toji Y., Matusda H., Raabe D., Effect of Si on the acceleration of bainite transformation by preexisting martensite. Acta Materialia, Vol.116, p250, 2016. 